\title{
Biomonitoring of selected persistent organic pollutants (PCDD/Fs, PCBs and PBDEs) in Finnish and Russian terrestrial and aquatic animal species
}

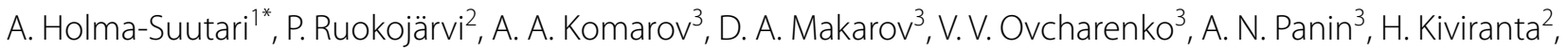 \\ S. Laaksonen ${ }^{4}$, M. Nieminen ${ }^{5}$, M. Viluksela ${ }^{2,6}$ and A. Hallikainen ${ }^{7}$
}

\begin{abstract}
Background: The Finnish and Russian animal species (semi-domesticated reindeer, Finnish wild moose, Baltic grey seal and Baltic herring) samples were biomonitored in terrestrial and aquatic environments for polychlorinated dibenzo-p-dioxins and dibenzofurans (PCDD/Fs), polychlorinated biphenyls (PCBs) and polybrominated diphenylethers (PBDEs).

Results: Grey seal (Halichoerus grypus) was clearly the most contaminated species. The mean PBDE concentration in grey seal was $115 \mathrm{ng} / \mathrm{g}$ fat, and the highest WHO-PCDD/F-PCB-TEQ (toxic equivalent set by WHO) was $327 \mathrm{pg} / \mathrm{g}$ fat. In Finnish, reindeer WHO-PCDD/F-TEQ varied from $0.92 \mathrm{pg} / \mathrm{g}$ fat in muscle to $90.8 \mathrm{pg} / \mathrm{g}$ fat in liver. WHO-PCDD/F-TEQ in moose liver samples was in the range of $0.7-4.26 \mathrm{pg} / \mathrm{g}$ fat, and WHO-PCB-TEQ in the range of $0.42-3.34 \mathrm{pg} / \mathrm{g}$ fat. Overall moose had clearly lower PCDD/F and DL-PCB concentrations in their liver than reindeer.

Conclusions: Terrestrial animals generally had low POP concentrations, but in reindeer liver dioxin levels were quite high. All Finnish and Russian reindeer liver samples exceeded the EU maximum level [8] for PCDD/Fs (10 pg/g fat), which is currently set for bovine animals.
\end{abstract}

Keywords: Biomonitoring, Animals, Dioxins, Liver, Organs

\section{Background}

Polychlorinated dibenzo- $p$-dioxins and dibenzofurans (PCDD/Fs), dioxin-like PCBs (DL-PCBs) and polybrominated diphenylethers (PBDEs) are lipophilic persistent organic pollutants with generally low water solubilities. They are threatening animals and humans when entering into the terrestrial and aquatic food chains [7]. These contaminants can cause severe health effects in humans and wildlife. Wild terrestrial animals, such as moose (Alces alces) and semi-domesticated reindeer (Rangifer tarandus tarandus), are known to accumulate environmental

\footnotetext{
*Correspondence: anniina.holmasuutari@outlook.com

${ }^{1}$ Department of Biology, University of Oulu, P.O. Box 3000, 90014 Oulu, Finland

Full list of author information is available at the end of the article
}

contaminants effectively, because their diet consists of plants from natural pastures contaminated due to longrange transport of atmospheric emissions [13]. Based on the studies on the other species (for e.g. sheep), different tissues of reindeer and moose are assumed to gather varying concentrations of contaminants.

From the aquatic point of view, the Baltic Sea is considered to be one of the most polluted waters in the world contaminated by Persistent organic pollutants (POPs). They are discharged from industrialized countries surrounding and transported from distant sources by an atmospheric deposition [23, 33]. There have been remarkable efforts to restrict the usage and production of the long-range transporting and bioaccumulate chemicals. However, they still can be found from the marine environment of the Baltic Sea [5]. It is considered that herring (Clupea harengus 
membras) and grey seal (Halichoerus grypus) from the Baltic Sea contain higher PBDE levels than the same or similar species from other waters. The adverse health effects of organohalogen chemicals have been seen clearly with grey seal, the population of which declined to minimum (about 4000 individuals) in the mid-1970s in the Baltic Sea because of reduction in pregnancy rates [12]. Thus, Baltic herring and grey seal may indicate well the contamination in aquatic environment. Mallard (Anas platyrhynchos), for its part, may indicate the contamination status of semiaqueous environment.

Atmospheric deposition is believed to be a major source of some POPs in the Baltic Sea [17, 33] and also in terrestrial environment, e.g. in Finnish Lapland [11]. The emissions of PBDEs to environmental compartments within the Baltic Sea region were recently estimated in the COHIBA Project (http://www.cohibaproject. net/home/en_GB/home/). While the emissions to land tended to originate mainly from the application of contaminated sewage sludge, the main emissions to air came during service life of flame-retarded products in the form of release from the indoor environment, steel industry and the accidental fires of waste.

In order to assess the exposure of people to POPs, it is important to notice that in Finland, hunting is a popular hobby among population, and over 300,000 people had an official hunting card in 2005 allowing them to hunt according to legislation (www.mmm.fi). Hunting big game, like moose, results that a group of people might consume more moose meat than pork or poultry meat. On the other hand, reindeer husbandry (including meat production and tourism, by-products) is an important livelihood in the northern Finland and also in Russia. Exposure to POPs via game meat, liver, and other organs may be a problem in some specific populations [7].

The distribution of PCDD/Fs and DL-PCBs in animal body has been studied in different animal species. There have been variations in the concentrations of contaminants in different tissues. Although fatty tissues are known to be the pool of lipophilic POPs, certain organs, such as liver, are high-risk edible tissues for dioxin-like pollutants [27]. Tissue distribution data have shown that liver has a higher potential to accumulate dioxin than the other tissues in rat [34], beef cattle [31], pig [27] and reindeer [29]. In the Danish study liver, leaf fat, flank and shank of sheep were analysed. The highest $\mathrm{PCDD} / \mathrm{Fs}$ were observed in sheep liver [20]. Furthermore, PCDD/Fs have been noticed to be 8-27 times higher in liver of sheep than its muscle tissue. However, similar phenomenon had not seen with the studied cows [26].

In the study of pigs, it was found that liver was again the main collector of dioxins when comparing compounds in liver, lung, kidney, subcutaneous fat, mesentery and muscle [27]. The property of liver to accumulate dioxins appeared also in the study of lamb organs: liver had clearly higher PCDD/Fs than kidneys and heart [9]. Offal products (e.g. paté, haggis, tripe and black budding) of the animals (lamb, ox, deer and pig) have generally low contaminant levels probably as a result of processing or dilution. On the other hand, quite high concentrations of PCDD/Fs and PCBs have been reported in some offals, such as deer and lamb liver, and consumption of portions more than $100 \mathrm{~g}$ may therefore lead to exceeded tolerably daily intake (TDI) ( $2 \mathrm{pg}$ WHO-TEQ/kg of body weight) $[9,7]$. Fish and fish products play a significant role in the Finnish dietary intake of polychlorinated dibenzo- $p$-dioxins, polychlorinated dibenzofurans ( $\mathrm{PCDD} / \mathrm{F}$; dioxins) and polychlorinated biphenyls (PCB). If one considers the $\mathrm{PCDD} / \mathrm{F}$ intake, then fish and fish products accounted for $82 \%$, and Baltic herring (C. harengus L.) alone $52 \%$ of the total intake [16].

In this study, POP concentrations have been reported in different terrestrial and aquatic animal species in Finland and Russia. The purpose was to report POP concentrations in the aquatic and terrestrial game species representing different environments and variable trophic levels in the ecosystem. Knowledge of organic pollutants in game and semi-domesticated animals is highly needed in order to give advice, if needed, to minimize the exposure of the hunting population.

\section{Methods}

\section{Terrestrial samples}

Organs of Finnish and Russian semi-domesticated reindeer were analysed for PCDD/Fs and DL-PCBs to figure out how contaminants are distributed in the reindeer body. Reindeer liver PCDD/F and DL-PCB concentrations were compared between adult reindeer and reindeer calves from Finnish Lapland and Kola Peninsula in Russia. In addition, PCDD/Fs and DL-PCBs were analysed in Finnish wild moose liver.

The reindeer tissue samples: muscle (rump, rib and shoulder muscle), liver, kidneys, abdominal fat, lymph nodes (from thoracic cavity) and bone marrow (from legs), lungs, brain, placenta (from adult female) and spleen were gathered from one adult female (age ca. 10 years) and one male calf (age ca. 6 months) from southern reindeer herding area in Finland in 2008. In addition, blood and udder samples were gathered from two adult female reindeer (age ca. 10 years) from northern reindeer herding area in Finland in 2010.

The Finnish reindeer liver samples were sampled in the northern (calves $n=5$, adult $n=5$ ), middle (calves $n=3$, adult $n=2$ ) and southern (calves $n=3$, adult $n=1$ ) Lapland in 2006 and 2010. The Russian reindeer liver $(n=7)$, 
muscle $(n=4)$ and kidney $(n=3)$ samples were gathered from adult reindeer in Lovozero district in Murmansk area, Kola Peninsula in 2013.

The sampling areas of Finnish moose liver samples located in Northern (Koillismaa) and Central (NorthSavo) Finland. The moose liver samples were pooled by the sampling area, sex and age. Pooling resulted in six samples: four from moose calves, age $<1$ year (of which two were individual moose livers, one pool with two subsamples and one pool with three subsamples), one young adult, age 1.5 years (one subsample,) and one pooled adult liver sample (two subsamples, ages 3 and 4 years).

In addition to individual reindeer and moose samples, in 2007, in a regular market surveillance, meat samples of semi-domesticated reindeer $(n=9)$ and moose $(n=3)$ were taken. Sampling and pooling complied the Commission regulation $1883 / 2006 / \mathrm{EC}^{4}$ and was targeted to the game or semi-domesticated reindeer sold in food stores representing different types and quality of meat. Samples included fillet, tenderloin, flank and rump. Also the muscle meat sample of European hare (Lepus europaeus) $(n=1)$ was collected from adult hare in southern Finland in 2007.

\section{Aquatic and semi-aquatic samples}

The muscle samples $(n=12)$ of Baltic herring were gathered from the Finnish market in 2006 and 2007. Origin of herring was the Baltic Sea; in particular Bothnian Sea and Archipelago Sea. A part of herring was sampled from unidentified area (Finnish) of the Baltic Sea. The muscle samples of grey seals were gathered as six pooled $(3 \times 300 \mathrm{~g})$ samples from different catching areas from the northern to southern Finnish coast of the Baltic Sea in 2006-2007. The samples were rolled to aluminium foil and packaged to Minigrip bags. The pooled muscle meat sample of mallard $(n=2)$ were collected from mallard in the middle of Finland in 2007.

\section{Sample preparation and analyses}

The tissues were cut using clean instruments and nitric gloves to prevent contamination. The samples were stored in polyethylene bags and preserved at $-20^{\circ} \mathrm{C}$ until the analysis was accomplished. The chemical analyses were carried out at the Chemical Exposure Unit of the National Institute for Health and Welfare. The laboratory has been accredited according to the EN ISO/IEC 17025 standard by FINAS. The scope of accreditation includes PCDD/F and DL-PCB analyses from biological matrices. The Russian samples were analysed with Waters Autospec system in the Russian State Center for Quality and Standardization of Veterinary Drugs and Feed (VGNKI). The institution is certified by RF Standardization, Metrology and Certification Committee (Gostandart) as the Veterinary Drugs and Feed certification and testing centre.

After homogenization, the samples were freeze dried, and fat was extracted with ethanol-toluene (15/85 \%, v/v) using Accelerated Solvent Extractor (Dionex ASE 300) equipment. The extraction solvent was evaporated to almost dryness and the samples were transferred into hexane, from which the fat content was measured gravimetrically. ${ }^{13} \mathrm{C}$-labelled PCDD/PCDF (altogether 16 standards) were used as internal standards to quantitate the amount of PCDDs/PCDFs. ${ }^{13} \mathrm{C}$-labelled PCB congeners were used as internal standards for non-ortho-PCBs. 13C-labelled PBDE standards (BDE 28, 47, 77, 99, 100, 153, 183 and 209) were used for quantification of PBDEs. The recoveries of the individual internal standards of $\mathrm{PCDD} / \mathrm{F}$ and $\mathrm{PCB}$ congeners were determined by adding the recovery standards just before mass spectral analysis. The recoveries of the internal standards were $60-120 \%$. The limits of quantification (LOQ) for individual congeners were determined by a signal-to-noise ratio of 3:1 [based on Commission regulation (EU) No 252/2012] in the chromatogram or in case of analyte peak existing in the blank sample, concentration of the analyte in blank sample.

After that slurry with sodium sulphate, silica gel, hexane and concentrated sulphuric acid was mixed with a sample. The sample slurry was poured into an acidic multilayer silica gel column [with sodium sulphate, sulphuric acid-silica gel (15 and $44 \% \mathrm{w} / \mathrm{w})$ and silica gel layers]. The sample was eluted from the column with hexane and concentrated into small volume $(0.5 \mathrm{ml})$ of hexane. The sample was further purified and fractionated on a carbon column with an alumina column on top of it. The columns were eluted with $20 \%$ dichloromethane-hexane $(\mathrm{v} / \mathrm{v})$ and the elute contained ortho and mono-ortho substituted PCBs.

The solvent was evaporated into $0.5 \mathrm{ml}$ of hexane, and after the addition of recovery standards, it was introduced into high-resolution gas chromatography-highresolution mass spectrometry (HRGC/HRMS; VG $70 \mathrm{SE}$ or Autospec Ultima). The carbon column was then inverted and eluted with toluene. After the addition of recovery standards into toluene fraction, it was evaporated into $20 \mu \mathrm{l}$ of nonane. This fraction containing $\mathrm{PCDD} / \mathrm{Fs}$ and non-ortho-PCBs was analysed with HRGC/HRMS; VG 70 SE or Autospec Ultima. The column used for PCDD/Fs and PCBs was DB-Dioxin column (J\&W Scientific, $60 \mathrm{~m}$, ID $0.25 \mathrm{~mm}, 0.15 \mu \mathrm{m}$ ). SIR was used with 10,000 resolution.

The analysed $\mathrm{PCDD} / \mathrm{F}$ congeners included 17 toxic 2378-substituted congeners (2378-TCDD, 12378-PeCDD, 123478-HxCDD, 123678-HxCDD, 123789-HxCDD, 1234678-HpCDD, OCDD, 2378-TCDF, 12378-PeCDF, 
23478-PeCDF, 123478-HxCDF, 123678-HxCDF, 234678HxCDF, 123789-HxCDF, 1234678-HpCDF, 1234789$\mathrm{HpCDF}$, OCDF). PCB congeners included 12 dioxin-like PCBs (Non-ortho-PCBs; -77, -81, -126, -169 and monoortho-PCBs; -105, -114, -118, -123, -156, -157, -167, -189). PBDEs consisted of congeners BDE-28, -75, -71, $-47,-66,-77,-100,-119,-99,-85,-154,-153,-138,-183$ and -209 .

The results are reported as fat-based lower bound concentrations i.e. the results below the limit of quantification (LOQ) are treated as zero.

\section{Results and discussion}

The fat-based WHO-PCDD/F-TEQ and WHO-PCBTEQ concentrations (lowerbound results) in Finnish reindeer are shown in Fig. 1.

It is seen that the concentrations of WHO-PCDD/Fand WHO-PCB-TEQs were quite equal in the studied organs. However, the liver is an exception, because it accumulates clearly more dioxin-like compounds than other organs. It may be the detoxification properties of liver, which makes it to gather toxic compounds in the greater extent than the other internal organs [21]. Some studies have shown that lipid difference in the tissues and the pollutant lipophilic property conducted transfer, cannot explain the elevated levels of dioxin-like compounds in liver. This may be the result of function of CYP1A2 in the liver. CYP1A2 is an important determinant of $\mathrm{PCDD} / \mathrm{F}$ sequestration. In addition, liver's high potency of accumulating pollutants may come from their physiological function as the biggest detoxification organ in mammals [27].

The reason for the elevated concentrations in the liver is called the first-pass effect. The venous blood from the gastrointestinal tract of all mammals, if not all vertebrates, is collected in the portal vein system and thus directly passed to the liver before reaching the rest of the body. Thus, the liver will always accumulate higher concentrations compared to the other organs simply because it is the organ that makes first contact within the blood flow.

WHO-PCDD/F-TEQ contributed more (69 \%) to total WHO-TEQ in liver while the contributions of WHOPCDD/F-TEQ and WHO-PCB-TEQ were more equal in other organs. However, WHO-PCB-TEQ shared $61 \%$ of total TEQ in bone marrow sample and even $92 \%$ of total TEQ in blood sample. The most abundant PCDD/F congeners in reindeer internal organs were 23478-PeCDF and 2378-TCDF. Of the non-ortho PCBs, the dominating congener was PCB-126, but also PCB-77 contributed significantly to the total non-ortho-PCB sum, especially in lymph nodes of reindeer.

PCDD/F- and DL-PCB concentrations (as fat-based WHO-TEQs) in Russian reindeer organ samples are shown in Table 1.

It can be noted that PCDD/F levels in Russian reindeer muscle, kidney and liver samples are close to Finnish reindeer samples, but DL-PCB concentrations in all

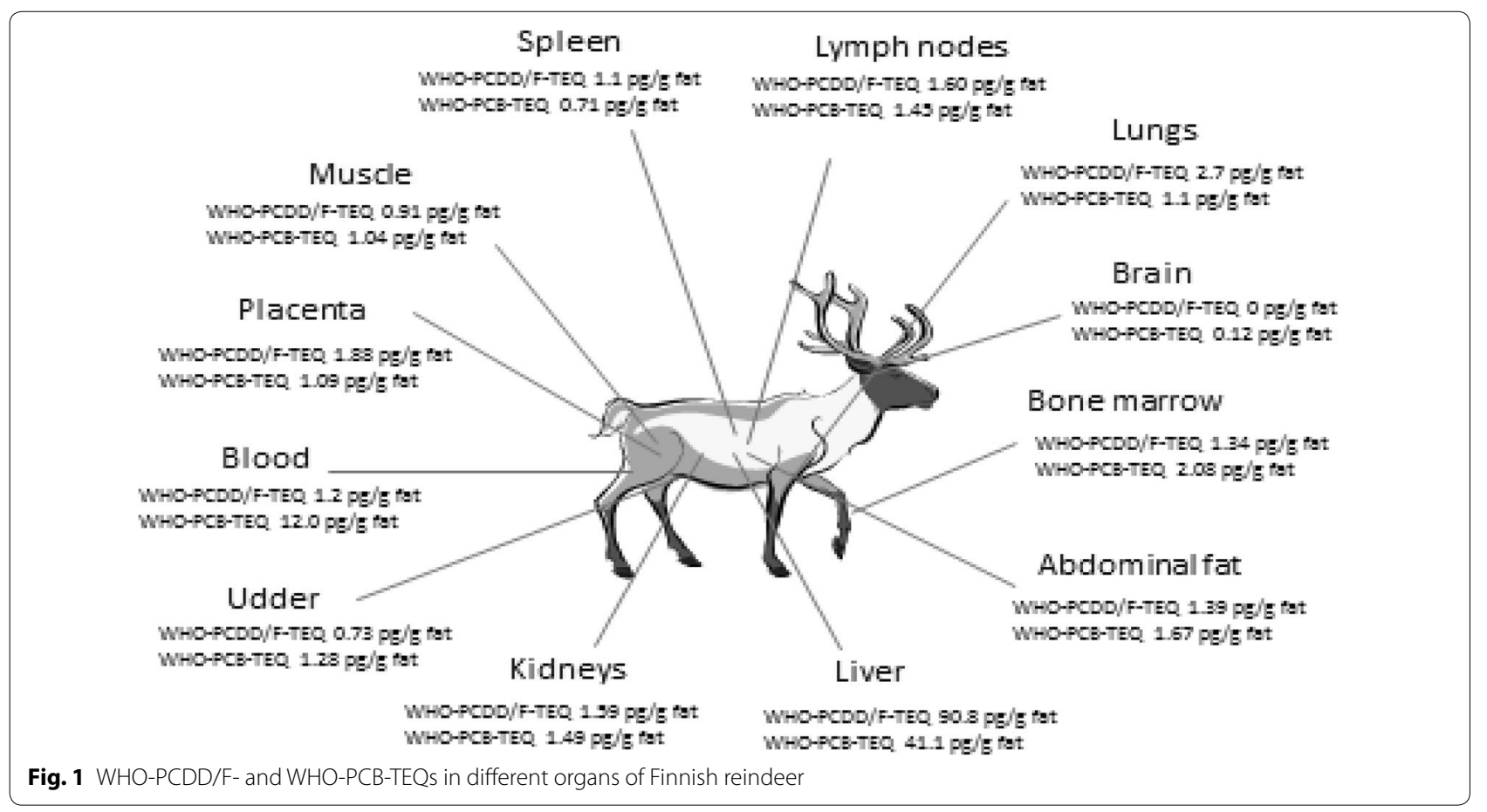


Table 1 WHO-PCDD/F-TEQs and WHO-PCB-TEQs (pg/g fat) in Russian reindeer organ samples (mean values)

\begin{tabular}{lcc}
\hline Sample & WHO-PCDD/F-TEQ & WHO-PCB-TEQ \\
\hline Reindeer muscle $(n=4)$ & 0.92 & 3.62 \\
Reindeer kidneys $(n=3)$ & 2.03 & 9.2 \\
Reindeer liver $(n=4)$ & 62.13 & 140.15 \\
\hline
\end{tabular}

tissues from Russia are several-fold higher than in tissues from Finland. The main contributor to toxicity equivalents in Russian samples was PCB-126. That may be point at a common intensive $\mathrm{PCB}$ contamination source located on the territory of Kola Peninsula.

Considering the food safety aspect, it is seen that $\mathrm{PCDD} / \mathrm{Fs}$ in Russian reindeer muscle samples are below the limits $(3 \mathrm{pg} / \mathrm{g}$ fat in Russia, $2.5 \mathrm{pg} / \mathrm{g}$ fat in EU), but total WHO-PCDD/F-PCB-TEQs are over the EU limit (4 pg/g fat). PCDD/Fs and DL-PCBs are ca. two times higher in kidneys than in muscle. PCDD/Fs in liver are higher by an order of magnitude than the current Russian limits $(6 \mathrm{pg} / \mathrm{g}$ fat).

$\mathrm{PCDD} / \mathrm{F}$ and DL-PCB concentrations (as fat-based WHO-TEQs) in Finnish and Russian reindeer liver samples are shown in Fig. 2. The results are compared to earlier studies on reindeer in Finland.

It is seen that in Finnish Lapland reindeer calves had higher WHO-PCDD/F- and WHO-PCB-TEQs than adult reindeer. The common trend in Finnish reindeer is that contaminant concentrations increase from northern to southern areas. However, the highest total TEQ level is observed in adult reindeer liver from Kola district, which is high in the north. It seems that in Kola Peninsula, there may be the local pollution sources which affect to the contaminant concentrations seen in reindeer liver.

In addition, WHO-PCDD/F-TEQs were quite equal in Russian adult reindeer liver samples and southern Lapland calf samples from Finland in 2006. That could mean there was also some local contamination source of $\mathrm{PCDD} / \mathrm{Fs}$ in southern Lapland, too. It is generally seen in the Finnish samples that liver accumulates more PCDD/ Fs than DL-PCBs. However, in the calf and adult reindeer samples from northern Lapland in 2010, there were more DL-PCBs than PCDD/Fs of total TEQs. Also adult reindeer samples from Kola district had relatively big contribution of DL-PCBs that may indicate the contamination source near the border area of Northern Finland and Russia in more recent years, while the samples of these areas had been collected in 2010-2013. The reindeer samples from northern Lapland in 2006 had smaller contribution of DL-PCBs of total TEQ than samples gathered in 2010. There could be varying exposure conditions between the years.

WHO-PCDD/F-TEQs and WHO-PCB-TEQs in Finnish moose liver are shown in Table 2.

It can be seen that a young adult moose from the central Finland had the highest WHO-PCDD-TEQ of the all samples studied $(4.26 \mathrm{pg} / \mathrm{g}$ fat). This may indicate

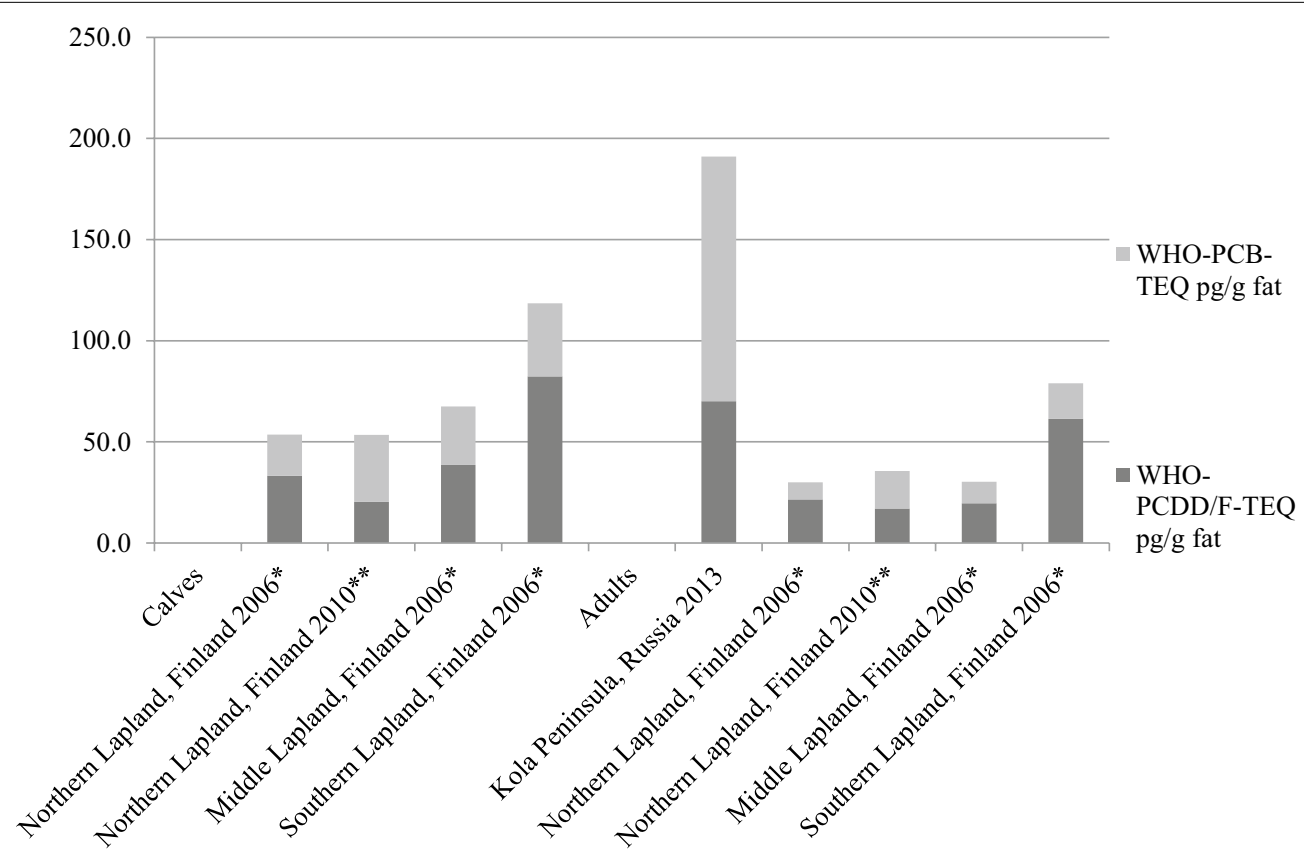

Fig. 2 WHO-PCDD/F- and WHO-PCB-TEQs in reindeer liver samples from Finnish Lapland and Kola Peninsula in Russia. *[13], **[29] 
higher exposure to $\mathrm{PCDD} / \mathrm{Fs}$ in more southern regions in Finland. The lowest WHO-PCDD/F-TEQ $(0.7 \mathrm{pg} / \mathrm{g}$ fat) and WHO-PCB-TEQ (0.42 pg/g fat) concentrations were seen in adult female moose from northern Finland. However, most of the calves from northern Finland had WHO-PCDD/F-TEQs and WHO-PCB-TEQs over $3.0 \mathrm{pg} / \mathrm{g}$ fat.

Low concentrations of WHO-PCB-TEQs of the calves and adult moose correlated with WHO-PCDD/F-TEQs: One moose calf and one moose adult had lower WHOPCB-TEQ concentrations than the other samples studied from the northern Finland. Lower WHO-PCB-TEQs of these samples may indicate different exposure conditions to PCBs. It has been found in earlier studies that Finnish reindeer calves' livers contained more $\mathrm{PCDD} / \mathrm{Fs}$ and DLPCBs than adult reindeer livers, which could be the case for moose as well [24, 29].

The fat contents of the moose liver samples were very similar (on average $5.3 \%$ ), so they do not explain variation in contamination levels. An earlier study does not support the concept that PCDD/Fs and DL-PCBs accumulate into liver tissue via the lipid partitioning only. Instead, there may be other functionally important factors such as CYP1A2, in liver [29]. In this study, we do not have information on moose liver enzymes in a relation to contaminant accumulation. However, accumulation of compounds in liver may be due to cytoplasmic and microsomal binding $[6,2]$. However, other than the DL-PCBs (namely non-DL-PCBs) can act as inhibitors of CYPs and may thus lead to reduced biotransformation.

In this study, adult moose from the northern Finland seemed to have somewhat lower DL-PCB concentrations than calves from the same area, but generally it seems that in northern Finland, there is higher exposure to DLPCBs than in southern Finland. This is supported by the observation that WHO-PCB-TEQs were generally higher in the northern than in southern Finland.
The most abundant PCDD/F congeners found in moose liver samples were 23478-PeCDF and 2378-TCDF. Also 123478-HxCDF, 123678-HxCDF and 234678-HxCDF were well representative in some of the liver samples. Of the non-ortho dioxin-like PCBs, the most dominating congener was clearly PCB-126.

A German study had observed that liver of roe deer (Capreolus capreolus) was highly contaminated with $\mathrm{PCDD} / \mathrm{Fs}$ and DL-PCBs in natural surroundings in Germany (WHO-PCDD/F-PCB-TEQ 61 pg/g fat) [25]. High levels have been detected in Finnish reindeer livers [24, 30], too. However, PCDD/F and PCB levels in reindeer and moose muscle samples were clearly lower than in liver in Finland [30]. White-tailed deer (Odocoileus virginianus) sampled near the magnesium smelter in Canada had PCDD/F-TEQ concentration of $26 \mathrm{pg} / \mathrm{g}$ fat in adipose tissue [32], which is still below the concentration in liver samples of reindeer in this study.

WHO-PCDD/F-PCB-TEQ in moose muscle samples in Sweden (on average $8.1 \mathrm{pg} / \mathrm{g}$ fat) [3] has shown higher level than moose muscle samples [30], and according to this study, also moose liver samples in Finland. This may indicate that Finnish moose is less exposed to PCDD/ Fs and DL-PCBs. However, contaminations of Finnish reindeer liver do not support the idea of minimal environmental pollution in Finland. There also can be some individual metabolic differences, which influence to the contamination levels in moose. A comparison of WHOPCDD/F-TEQs and WHO-PCB-TEQs between Finnish reindeer and moose muscle and liver is shown in Fig. 3.

It is clearly seen that moose have lower concentrations of PCDD/Fs and DL-PCBs in liver than reindeer. It could be possible that there are naturally more binding CYP1A2 enzymes in reindeer liver than in moose liver. Other explanation may be that moose is metabolizing these compounds more effectively than reindeer. Or, it could be the differences in the diets of these Cervid species which have influence to PCDD/F and DL-PCB levels

Table 2 WHO-PCDD/F- and PCB-TEQs (pg/g fat) in moose liver samples

\begin{tabular}{|c|c|c|c|c|}
\hline \multirow[t]{2}{*}{ Sample } & \multirow[t]{2}{*}{$n$} & \multirow[t]{2}{*}{ Fat $\%$} & \multirow{2}{*}{$\begin{array}{l}\text { WHO-PCDD/F-TEQ } \\
\text { TEF } 2005 \text { (1998) }\end{array}$} & \multirow{2}{*}{$\begin{array}{l}\text { WHO-PCB-TEQ } \\
\text { TEF } 2005 \text { (1998) }\end{array}$} \\
\hline & & & & \\
\hline \multicolumn{5}{|l|}{ Northern Finland } \\
\hline Moose calf male \#1 & $1^{\mathrm{a}}$ & 4.9 & $3.03(4.11)$ & $3.34(3.35)$ \\
\hline Moose calf female \#2 & $1^{\mathrm{a}}$ & 5.4 & $1.08(1.44)$ & $0.94(0.94)$ \\
\hline Moose calf female \#3, (age $8+8$ months) & $2^{\mathrm{b}}$ & 5.4 & $3.82(5.34)$ & $3.27(3.27)$ \\
\hline Moose calf female \#4 & $3^{b}$ & 5.3 & $3.53(4.86)$ & $3.28(3.28)$ \\
\hline Moose adult female \#5, (age $3+4$ years) & $2^{b}$ & 5.1 & $0.7(0.98)$ & $0.42(0.42)$ \\
\hline \multicolumn{5}{|l|}{ Central Finland } \\
\hline Moose young adult \#6, (age 1.5 years) & $1^{\mathrm{a}}$ & 5.4 & $4.26(5.71)$ & $2.65(2.66)$ \\
\hline
\end{tabular}

a Sample consists of one individual. ${ }^{\mathrm{b}}$ Sample consists of two or three individuals pooled together. Fat content (\%) are relative to wet weight 


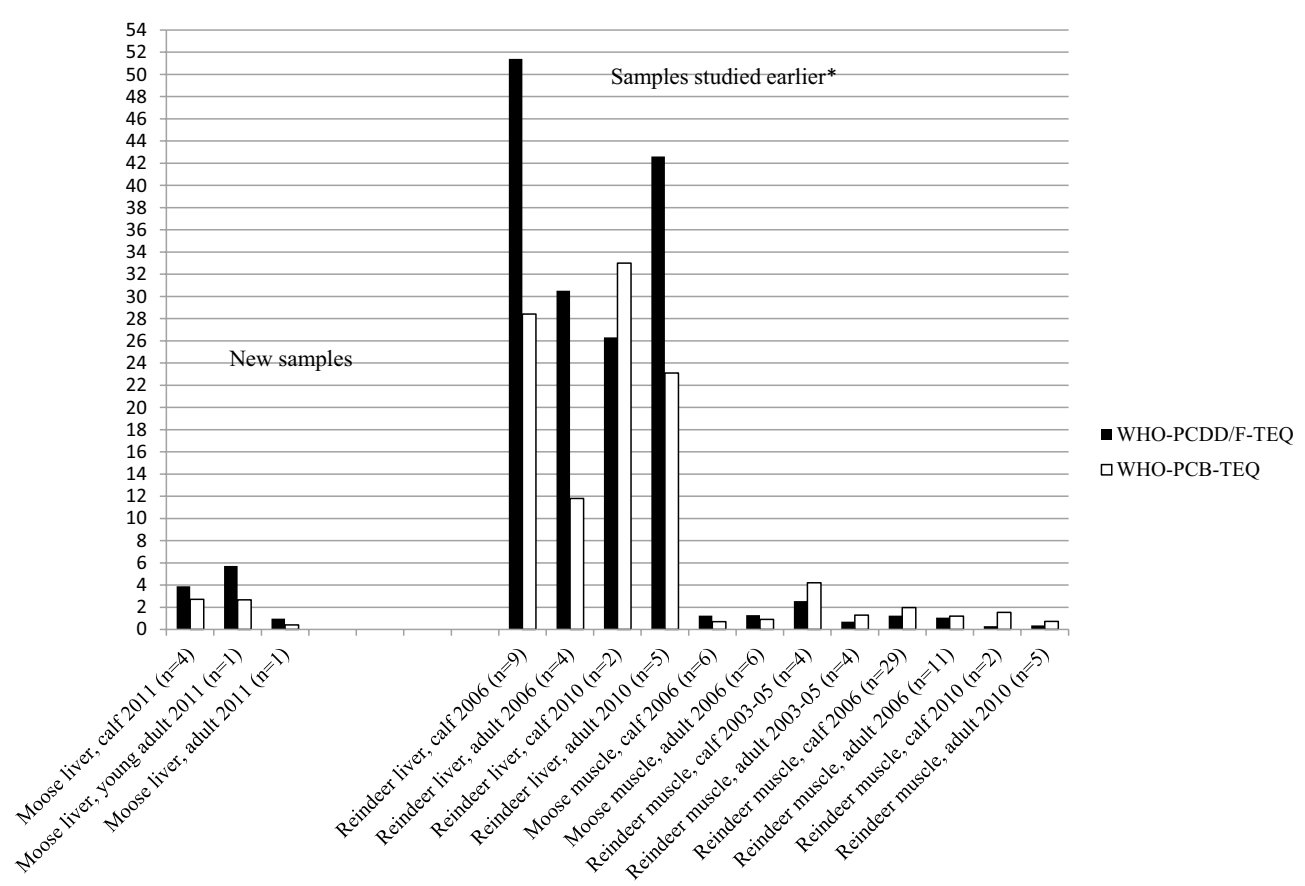

Fig. 3 WHO-PCDD/F-TEQs and WHO-PCB-TEQs (pg/g fat, calculated as TEFs 1998) in Finnish moose liver compared to the earlier results of contaminants in reindeer and moose tissues. ${ }^{*}[13,29,30]$

in their liver. It is also possible that all these explanations are affecting to the outcome.

In hare meat, the concentrations of WHO-PCDD/FTEQ were $1.2 \mathrm{pg} / \mathrm{g}$ fat and WHO-PCB-TEQ $0.89 \mathrm{pg} / \mathrm{g}$ fat. It is seen that PCDD/Fs contributed more to total WHO-TEQ in hare. PBDE concentration was $1.7 \mathrm{ng} / \mathrm{g}$ fat. BDE-209 was clearly the most dominating PBDE congener in hare.

PBDE congener profile in reindeer was largely different than in Baltic herring and grey seal. BDE-209 was the most dominating congener; its share was as much as $79 \%$ of total PBDE sum. BDE-47 (6 \%), BDE-99 (6 \%) (Indicators of Penta-mix exposure) and BDE-153 (5\%) were three other congeners building mainly PBDE congener profile of reindeer. BDE-154 and -183 (Octa-mix congeners) were observed to show low contribution (1\% from total sum) in reindeer. An earlier study with moose $(A$. alces) in Finland had shown that Penta- and Octa-BDEs were the most dominating PBDEs in muscle samples. However, BDE-209 has been observed to exist in high levels (up to $177 \mathrm{ng} / \mathrm{g}$ lipid weight) in moose muscle samples, too [29]. It is concluded that BDE-209 is minimally absorbed from the gastrointestinal tract of mammals because of its high molecular mass [4]. Our study, however, shows high BDE-209 levels in terrestrial herbivore mammals.
The mean WHO-PCDD/F-TEQ was $22 \mathrm{pg} / \mathrm{g}$ fat and WHO-PCB-TEQ $191 \mathrm{pg} / \mathrm{g}$ fat in grey seal (Table 3). In the meat of grey seal, the concentration of dioxins was clearly higher when compared to results in terrestrial animals implicating their different position in the food web. There may be harmful health effects for grey seal because of high dioxin contamination. The contribution of PCB to total TEQ was higher in grey seal while the opposite was true for meat of moose, mallard and hare (Table 4) as well as for liver of reindeer.

It was observed that grey seal had clearly the highest mean PBDE concentrations, $115 \mathrm{ng} / \mathrm{g} \mathrm{lw}$ ) (Table 5). The secondly highest PBDE level was observed to be in Baltic herring (12.2 $\mathrm{ng} / \mathrm{g} \mathrm{lw})$, followed by reindeer $(1.85 \mathrm{ng} / \mathrm{g}$ lw). The lipid content was on average highest in Baltic herring (9.5\%). Grey seal (4.6\%) and reindeer (3.4\%) had more equal fat contents. Therefore, it is not a necessity to have a highest lipid content to have the highest PBDE levels in muscle tissue as the results with grey seal indicate. It may be still the ecophysiological factors, like feeding behaviour and metabolic capacity, which affect to the PBDE concentrations detected in animal tissues.

Considering the individual PBDE congeners in Baltic herring, a proportion of BDE-47 was remarkable, namely $59 \%$, and it was followed by BDE-100 with $14 \%$ share of total PBDEs measured (Table 2). Though, this indicates 
Table 3 Dioxin concentrations in grey seal samples

\begin{tabular}{|c|c|c|c|c|c|c|c|c|c|}
\hline Sample & Area & Fat $\%$ & $\begin{array}{l}\mathrm{PCDD} / \mathrm{F} \\
\text { (pg/g fat) }\end{array}$ & $\begin{array}{l}\text { DL-PCB } \\
\text { (pg/g fat) }\end{array}$ & $\begin{array}{l}\text { PCB (ng/g } \\
\text { fat) }\end{array}$ & $\begin{array}{l}\text { WHO-PCDD/ } \\
\text { F-TEQ (pg/g } \\
\text { fat) }\end{array}$ & $\begin{array}{l}\text { WHO-NO- } \\
\text { PCB-TEQ } \\
\text { (pg/g fat) }\end{array}$ & $\begin{array}{l}\text { WHO-PCB- } \\
\text { TEQ (pg/g fat) }\end{array}$ & $\begin{array}{l}\text { WHO-PCDD/F- } \\
\text { PCB-TEQ (pg/g } \\
\text { fat) }\end{array}$ \\
\hline Seal & North-Finland & 9.5 & 76.7 & 557,503 & 22,900 & 23 & 46 & 190 & 213 \\
\hline Seal & $\begin{array}{l}\text { South-West- } \\
\text { Finland }\end{array}$ & 9.2 & 81.7 & 229,718 & 7580 & 21.6 & 24.2 & 77 & 98.6 \\
\hline Seal & $\begin{array}{l}\text { South-West- } \\
\text { Finland }\end{array}$ & 2.2 & 60.5 & 215,644 & 9450 & 12.6 & 17.9 & 70.8 & 83.4 \\
\hline Seal & South-Finland & 3.5 & 186 & 803,950 & 28,100 & 31.2 & 56.8 & 270 & 301.2 \\
\hline Seal & West-Finland & 2.4 & 107 & 517,230 & 15,000 & 33.5 & 50.5 & 192 & 225.5 \\
\hline Seal & North-Finland & 0.7 & 125 & 838,231 & 53,000 & 8.84 & 27.4 & 318 & 326.84 \\
\hline
\end{tabular}

Fat content (\%) are relative to wet weight

a NO Non-ortho-PCB

Table 4 Median upper bound concentrations of WHOPCDD/F-TEQs and WHO-PCB-TEQs in different market surveillance samples in Finland in 2007

\begin{tabular}{lllll}
\hline Sample & $\boldsymbol{n}$ & Fat \% & WHO-PCDD/F-TEQ & WHO-PCB-TEQ \\
\hline Reindeer & & & & \\
Fillet & 1 & 3.8 & 1.0 & 1.7 \\
Rump & 3 & 2.7 & 1.2 & 1.9 \\
Tenderloin & 1 & 2.8 & 1.1 & 1.8 \\
Flank & 1 & 4.0 & 2.2 & 6.9 \\
Moose & & & & \\
Rump & 3 & 1.7 & 0.92 & 0.25 \\
Mallard & 1 & 19 & 0.88 & 0.047 \\
Hare & 1 & 3.3 & 1.2 & 0.89 \\
\hline
\end{tabular}

Fat content (\%) are relative to wet weight

strong Penta-mix exposure of Baltic herring. Parallel results have been observed by previous studies on Baltic herring $[15,22]$. BDE-47 is typically found from animals in the marine environment. For example, in the livers of piscivorous cormorants (Phalocrocorax carbo) BDE-47 contributed $24-100 \%$ of the total PBDEs present $[1,18]$. Haglund et al. [10] have reported BDE-47 concentrations $3.2-27 \mu \mathrm{g} / \mathrm{kg}$ lipid weight in different age groups of Baltic herring. Though, age-related accumulation of PBDEs in fish had been observed [28]. Shares of BDE-99, -154 and -209 were quite equal (on average $6 \%$ of each) in Baltic herring.

The most dominant PBDE congeners in grey seal were BDE- 47 and -100 as they were in Baltic herring, too (Table 2). BDE-47 was contributed on average $68 \%$ of the total PBDE sum of grey seal. Contribution of BDE-100 was $9 \%$. In contrast to high BDE-47 concentration and thus indication of the presence of Penta-BDE formulation, the Octa-mix indicative BDE-183 concentration was negligible in the grey seal samples (that was true also for Baltic herring). However, BDE-154 and -153 (Octa-mix exposure indicators) have on average $5 \%$ representation of total PBDE profile in grey seal.

BDE-28 and -66 were not seen in grey seal samples although these congeners exist in Baltic herring samples ( $2 \%$ contribution both). This may be explained by the higher metabolic rate of these congeners in grey seal. Tetra- to Hexa-BDEs have been reported found widely from the wildlife in remote areas $[14,19]$.

The overall PBDE congener profile of Baltic herring reflected well a profile of grey seal; correlation coefficient was 0.99 between the species. Only exceptions were early mentioned BDE-66 and -28. Species-specific differences in accumulation of compounds may be

Table 5 PBDE concentrations [mean, (SD), range] along with the fat contents (relative to wet weight) in aquatic and terrestrial samples

\begin{tabular}{lllll}
\hline Sample & $\mathbf{n}$ & Fat $\%$ & PBDE (ng/g ww) & PBDE (ng/g lw) \\
\hline Baltic herring & 12 & $9.5(3.2) 6.0-19.0$ & $0.4(0.7) 0.0-2.0$ & $12.2(7.0) 4.2-26.3$ \\
Grey seal & 6 & $4.6(3.8) 0.7-9.5$ & $5.2(4.8) 0.74-13.4$ & $115.0(59.4) 47.6-212$ \\
Mallard & $1($ sub- $n=2)$ & 19.5 & 0.17 & 0.88 \\
Reindeer & 14 & $3.4(1.34) 1.4-5.8$ & $0.06(0.11) 0.004-0.44$ & $1.85(2.52) 0.12-7.57$ \\
Moose & 3 & $2(0.96) 1.0-3.3$ & $0.017(0.006) 0.01-0.03$ & $1.24(0.94) 0.36-2.55$ \\
European hare & 1 & 3.3 & 0.06 & 103 \\
\hline
\end{tabular}


caused by absorption efficiency, elimination rates and/or metabolism.

\section{Conclusions}

Dioxin concentrations in the meat of semi-domesticated reindeer and terrestrial game animals were generally low. However, reindeer liver contained about 20 times more $\mathrm{PCDD} / \mathrm{Fs}$ when compared to reindeer meat. PCDD/Fs were quite equally distributed in the lipid compartment in all Finnish reindeer tissues, despite the varying fat contents in different tissues. However, in liver there was overwhelmingly highest PCDD/F level. That may be the result of existing CYP1A2 and high affinity of dioxin-like compounds to it. DL-PCBs were behaved with similar manner than PCDD/Fs. However, there was somewhat higher DL-PCB concentration in bone marrow than in other organs. Again liver was an exception with the highest DL-PCB load.

Reindeer liver samples showed varying concentrations of PCDD/Fs and DL-PCBs. Finnish reindeer calves had higher contaminant levels than adult reindeer, but adult reindeer from Kola Peninsula showed to have the highest concentration of total TEQ (ca. $190 \mathrm{pg} / \mathrm{g}$ fat). All Finnish and Russian reindeer liver samples exceeded the EU maximum level for PCDD/Fs (10 pg/g fat), which is currently set for bovine animals.

A young adult moose from the central Finland had the highest concentrations of PCDD/Fs and DL-PCBs of all moose liver samples studied. Generally studied calves from the northern sampling site had equal concentrations of WHO-PCDD/F- and WHO-PCB-TEQs in their liver. Overall moose had clearly lower PCDD/F and DL$\mathrm{PCB}$ concentrations in their liver than reindeer. There could be differences between the diets or metabolic capacities or both.

Grey seal had clearly the highest mean PBDE concentrations. The secondly highest PBDE level was observed to be in Baltic herring, followed by reindeer. PBDE congener profiles were very similar in Baltic herring and grey seal (representing an aquatic food chain). However, PBDE profiles in terrestrial environment differed significantly from aquatic one. This may indicate different deposition mechanisms and exposure of PBDEs and also possible different biotransform capacity of animals.

Being herbivores, terrestrial animals have congener profiles closer to deposited (technical) mixtures of PCBs and PBDEs when compared to e.g. Baltic Sea seal (tetraand penta congeners of PCBs and congeners BDE47, 99 and 100 contribute significantly).

\section{Authors' contributions}

AHS performed sampling and data analyses and wrote the manuscript. PR performed chemical analyses and prepared the manuscript. AK performed data analyses. DM performed data analyses and prepared the manuscript. VO performed data analyses. AP performed data analyses. HK performed chemical analyses and prepared the manuscript. SL performed sampling and data analyses and prepared the manuscript. MN prepared the manuscript. MV prepared the manuscript preparing. AH performed data analyses and prepared the manuscript. All authors read and approved the final manuscript.

\section{Author details}

${ }^{1}$ Department of Biology, University of Oulu, P.O. Box 3000, 90014 Oulu, Finland. ${ }^{2}$ Department of Environmental Health, National Institute for Health and Welfare, P.O. Box 95, 70701 Kuopio, Finland. ${ }^{3}$ The All-Russian State Center for Quality and Standardization of Veterinary Drugs and Feed (VGNKI), Zvenigorodskoe Highway 5, Moscow, Russian Federation 123022. ${ }^{4}$ University of Helsinki, Nurminiementie 2, 93600 Kuusamo, Finland. ${ }^{5}$ Reindeer Research Station, Finnish Game and Fisheries Research Institute, Toivoniementie 246, 99100 Kaamanen, Finland. ${ }^{6}$ Department of Environmental and Biological Sciences, University of Eastern Finland, 70211 Kuopio, Finland. ${ }^{7}$ Risk Assessment Research Unit, Finnish Food Safety Authority Evira, Mustialankatu 3, 00790 Helsinki, Finland.

\section{Acknowledgements}

Finnish Food Safety Authority Evira, Finnish Cultural Foundation and Thuleinstitute and Oulun läänin Talousseuran maataloussäätiö are acknowledged for funding of this study. The staff of Unit of Chemical Exposure in THL is thanked for their technical assistance.

\section{Competing interests}

The authors declare that they have no competing interests.

Received: 13 October 2015 Accepted: 27 January 2016

Published online: 11 February 2016

\section{References}

1. Allchin CR, Morris S, Bennett M, Law RJ, Russell I (2000) Polybrominated diphenyl ether residues in cormorant (Phalocrocorax carbo L.) livers from England, UK. Organohalog Compd 47:190-194

2. Bell D, Clode S, Fan M, Fernandes A, Foster P, Jiang T, Loizou G, MacNicoll A, Miller B, Rose M, Tran L (2007) Toxicity of 2,3,7,8-tetrachlorodibenzop-dioxin (TCDD) in the developing male Wistar (Han) rat Il: chronic dosing causes developmental delay. Toxicol Sci 99:214-223

3. Danielsson S, Odsjö T, Bignert A, Remberger M (2008) Organic contaminants in moose (Alces alces) and reindeer (Rangifer tarandus) in Sweden from the past twenty years. Swedish Museum of Natural History. Report Nr. 7.pp 43

4. Darnerud PO, Eriksen GS, Jóhannesson T, Larsen PB, Viluksela M (2001) Polybrominated diphenyl ethers: occurence, dietary exposure and toxicology. Environ Health Perspect 109:49-68

5. Darnerud PO, Atuma S, Aune M, Bjerselius R, Glynn A, Peterson Grawé K, Becker W (2006) Dietary intake estimations of organohalogen contaminants (dioxins, PCB, PBDE and chlorinated pesticides, e.g. DDT) based on Swedish market basket data. Food Chem Toxicol 44:1597-1606

6. Diliberto JJ, Jackson JA, Birnbaum LS (1996) Comparison of 2,3,7,8-tetrachlorodibenzo- $p$-dioxin (TCDD) disposition following pulmonary, oral, dermal and parenteral exposures to rats. Toxicol Appl Pharmacol 138:158-168

7. European Commission (2001) (2001/C 322/02). COM (2001) 593 final

8. European Commission (2011) Regulation 1259/2011/EC

9. Fernandes A, Mortimer D, Rose M, Gem M (2010) Dioxins (PCDD/Fs) and PCBs in offal: occurrence and dietary exposure. Chemosphere 81:536-540

10. Haglund PS, Zook DR, Buser H-R, Hu J (1997) Identification and quantification of polybrominated diphenyl ethers and mehoxy-polybrominated diphenyl ethers in baltic biota. Environ Sci Technol 31:3281-3287

11. Hansson K, Palm Cousins A, Broström-Lunden E, Leppänen S (2006) Atmospheric concentrations in air and deposition fluxes of POPs at Råö and Pallas, trends and seasonal and spatial variations. IVL Report U1967

12. Harding KC, Härkönen TJ (1999) Development in the Baltic Grey seal (Halichoerus grypus) and ringed seal (Phoca hispida) populations during yhe 20th century. Ambio 28:619-627

13. Holma-Suutari A, Ruokojärvi $P$, Laaksonen S, Kiviranta H, Nieminen M, Viluksela M, Hallikainen A (2014) Persistent organic pollutant levels in 
semi-domesticated reindeer (Rangifer tarandus tarandus L.), feed, lichen, blood, milk, placenta, foetus and calf. Sci Total Environ 476-477:125-135

14. Jansson B, Asplund L, Olsson M (1987) Brominated flame retardantsubiquitous environmental pollutants? Chemosphere 16:2343-2349

15. Kierkegaard A, Björklund J, Fridén U (2004) Identification of the flame retardant decabromodiphenyl ethane in the environment. Environ Sci Technol 38:3247-3253

16. Kiviranta H, Hallikainen A, Ovaskainen M-L, Kumpulainen J, Vartiainen T (2001) Dietary intakes of polychlorinated dibenzo-p-dioxins, dibenzofurans and polychlorinated biphenyls in Finland. Food Addit Contam 18:945-953

17. Koistinen J, Kiviranta H, Ruokojärvi P, Parmanne R, Verta M, Hallikainen A, Vartiainen T (2008) Organohalogen pollutants in herring from the northern Baltic Sea: concentrations, congener profiles and explanatory factors. Environ Pollut 154:172-183

18. Law RJ, Allchin CR, Bennett ME, Morris S, Rogan E (2002) Polybrominated diphenyl ethers in two species of marine top predators from England and Wales. Chemosphere 46:673-681

19. Law RJ, Alaee M, Allchin CR, Boon JP, Lebeuf M, Lepom P, Stern GA (2003) Levels and trends of polybrominated diphenylethers and other brominated flame retardants in wildlife. Environ Inter 29:757-770

20. Lund KH, Sørensen S, Cederberg TL (2008) PCDD/F and PCB content in different parts of sheep. Organohalogen Compd 70:001724

21. Nebert DW, Gonzalez FJ (1987) P450 genes: structure, evolution, and regulation. Annu Rev Biochem 56:945-993

22. Parmanne R, Hallikainen A, Isosaari P, Kiviranta $H$, Koistinen J, Laine O, Rantakokko P, Vuorinen PJ, Vartiainen T (2006) The dependence of organohalogen compound concentrations on herring age and size in the bothnian sea, northern baltic. Mar Pollut Bull 52:149-161

23. Roots O, Zitko V, Roose A (2005) Persistent organic pollutant patterns in grey seals (Halichoerus grypus). Chemosphere 60:914-921

24. Ruokojärvi P, Suutari A, Hallikainen A, Laaksonen S, Nieminen M, Kiviranta $H(2011)$ Distribution of PCDD/Fs, PCBs and PBDEs in semidomesticated reindeer (Rangifer tarandus tarandus L.) meat and liver. Organohalogen Compd 73:1321-1324

25. Schröter-Kermani C, Rappolder M, Neugebauer F, Päpke O (2011) PCDD, $P C D F$, and DL-PCB in terrestrial ecosystems: are there correlations of levels or patterns in soil and roe deer liver? Organohalogen Compd 73:1325-1328
26. Schultz AJ, Wiesmüller T, Appuhn H, Stehr D, Severin K, Landmann D, Kamphues J (2005) Dioxin concentration in milk and tissues of cows and sheep related to feed and soil contamination. J Anim Physiol Anim Nutr 89:72-78

27. Shen $H$, Henkelmann B, Rambeck WA, Mayer R, Wehr U, Schramm KW (2012) Physiologically based persistent organic pollutant accumulation in pig tissues and their edible safety differences: an in vivo study. Food Chem 132:1830-1835

28. Strandman T, Koistinen J, Kiviranta H, Vuorinen PJ, Tuomisto J, Tuomisto J, Vartiainen T (1999) Levels of some polybrominated diphenyl ethers (PBDEs) in fish and human adipose tissue in Finland. Organohalogen Compd 40:355-358

29. Suutari $A$, Ruokojärvi $P$, Kiviranta $H$, Verta $M$, Korhonen $M$, Nieminen $M$, Laaksonen S (2011) Polychlorinated dibenzo-p-dioxins (PCDDs), dibenzofurans (PCDFs), polychlorinated biphenyls (PCBs), and polybrominated diphenyl ethers (PBDEs) in Finnish semi-domesticated reindeer (Rangifer tarandus tarandus L.). Environ Int 37:335-341

30. Suutari A, Ruokojärvi P, Hallikainen A, Kiviranta H, Laaksonen S (2009) Polychlorinated dibenzo- $p$-dioxins, dibenzofurans, and polychlorinated biphenyls in semi-domesticated reindeer (Rangifer tarandus tarandus) and wild moose (Alces alces) meat in Finland. Chemosphere 75:617-622

31. Thorpe S, Kelly M, Startin J, Harrison N, Rose M (2001) Concentration changes for 5 PCDD/F congeners after administration in beef cattle. Chemosphere 43:869-879

32. Tolley C, Blais JM (2007) Polychlorinated dibenzo-p-dioxin, polychlorinated dibenzofuran, and polychlorinated biphenyl accumulation in whitetailed deer (Odocoileus virginianus) near a magnesium smelter in Quebec, Canada. Environ Toxicol Chem 26:2650-2659

33. Verta M, Salo S, Korhonen M, Assmuth T, Kiviranta H, Koistinen J, Ruokojärvi P, Isosaari P, Berqvist P-A, Tysklind M, Cato I, Vikelsoe J, Larsen MM (2007) Dioxin concentrations in sediments of the Baltic Sea: a survey of existing data. Chemosphere 67:1762-1775

34. Viluksela M, Duong TV, Stahl BU, Li XL, Tuomisto J, Rozman KK (1996) Toxicokinetics of 2,3,7,8-tetrachlorodibenzo-p-dioxin (TCDD) in two substrains of male long-evans rats after intravenous injection. Fundam Appl Toxicol 31:184-191

\section{Submit your manuscript to a SpringerOpen ${ }^{\odot}$ journal and benefit from:}

- Convenient online submission

- Rigorous peer review

- Immediate publication on acceptance

- Open access: articles freely available online

- High visibility within the field

- Retaining the copyright to your article

Submit your next manuscript at $>$ springeropen.com 